\title{
16. PERMEABILITY AND STRESS HISTORY OF SEDIMENT FROM THE CASCADIA MARGIN ${ }^{1}$
}

\author{
K. Moran, ${ }^{2}$ W.G.D. Gray, ${ }^{3}$ and C.A. Jarrett ${ }^{4}$
}

\begin{abstract}
Sediment physical and geotechnical properties from Ocean Drilling Program Leg 146 Sites 891 and 892 on the Cascadia Margin are presented. The data are interpreted in terms of stress history, permeability, and excess pore-fluid pressures. The results show two different patterns of sediment stress history: underconsolidation and normal consolidation. Normal consolidation occurs in the upper sediment units at both sites. Underconsolidation occurs at both sites within sediment units that have been loaded by overthrusted sediment. Test results from the underconsolidated units are further interpreted in terms of excess fluid pressures.
\end{abstract}

\section{INTRODUCTION}

The Cascadia Margin accretionary prism comprises Pliocene and younger turbidite and distal fan sediments originally deposited in the Cascadia Basin. Convergent plate motion at the Cascadia Margin subducts the Juan de Fuca plate and offscrapes a portion of the overlying Cascadia Basin sediment into the accretionary prism. This process stresses the sediments, resulting in excess pore pressures and fluid flow. The importance of pore fluids in accretionary prism deformation has been known for some time (Hubbert and Rubey, 1959; Davis et al. 1983), yet this role is still not fully understood (Langseth and Moore, 1990). Realistic modeling of accretionary prism development requires knowledge of: (1) pore fluid flow and expulsion, on which an important constraint is sediment permeability; (2) deformation behavior, which is controlled by sediment compressibility and strength; and (3) stress history, which defines the strength and pore pressure of the sediment during its evolution in the prism. This study provides laboratory test results and analyses of sediment permeability, compressi-bility and stress history for two sites on the Oregon Margin: 891 and 892 (Fig. 1). Site 891 is located on the westernmost ridge of the Oregon Continental Margin, approximately $1.9 \mathrm{~km}$ landward of the seabed expression of a major thrust fault. Site 892 lies near the crest of the second ridge of the accretionary prism off central Oregon.

\section{METHODS}

Two test methods are used in this study: low-gradient permeability and one-dimensional consolidation tests. The low-gradient permeability tests provide direct measurement of the sediment hydraulic conductivity, which is sometimes referred to as the coefficient of permeability $(\mathrm{K})$. The one-dimensional consolidation tests define sediment compressibility and stress history. Estimates of permeability from consolidation tests are compared with the direct measurements from low-gradient tests. The stress history results are also compared

'Carson, B., Westbrook, G.K., Musgrave, R.J., and Suess, E. (Eds.), 1995. Proc. ODP, Sci. Results, 146 (Pt. 1): College Station, TX (Ocean Drilling Program).

${ }^{2}$ Geological Survey of Canada, Bedford Institute of Oceanography, Dartmouth, Nova Scotia B2Y 4A2, Canada.

${ }^{3}$ Department of Earth Sciences, Dalhousie University, Halifax, Nova Scotia B3H 3J5. Canada.

${ }^{4}$ AK Geoservices, Dartmouth, Nova Scotia, B2Y 4A2 Canada. to stress histories inferred from porosity-depth functions and normalized undrained shear strength-depth relationships.

\section{Low-gradient Permeability}

The sediment property that describes the rate of fluid flow is hydraulic conductivity or Darcy's coefficient of permeability. Values of hydraulic conductivity are derived using Darcy's Law. The hydraulic conductivity represents the properties of the sediment matrix and the properties of the pore fluid. The property of the sediment matrix alone is known as the intrinsic permeability. The relationship between the hydraulic conductivity and the intrinsic permeability of that material is given by the following:

$$
K=k \rho g / \mu
$$

where $K$ is hydraulic conductivity, $k$ is intrinsic permeability, $\rho$ is pore fluid density, $g$ is gravitational acceleration, and $\mu$ is fluid viscosity. Hydraulic conductivity testing in the laboratory typically involves the use of either a constant-head permeameter or a fallinghead permeameter. These devices pass water through a sediment sample of known height and cross-sectional area, allowing calculation of hydraulic conductivity using Darcy's law. These devices are not suitable for use with very fine-grained materials because the Darcy relationship is non-linear under high-gradient conditions. For this reason, this study uses a low flow pump to measure hydraulic conductivity. This technique establishes a precisely controlled rate of flow through a sample within a closed, saturated system. This known rate of flow replaces the requirement for measuring flow rate. A differential pressure transducer measures the resulting gradient across the sample. All permeability results are reported as hydraulic conductivity values and can be converted to intrinsic permeability using Equation 1.

\section{One-dimensional Consolidation Tests}

The term consolidation is used in many contexts, often incorrectly. Geologists frequently use the term to suggest a degree of cohesiveness within a sedimentary unit, perhaps better regarded as the degree of lithification. In this study, consolidation is defined, following Terzaghi (1943), as the change in the volume of voids within saturated sediment that results from a decrease in water content. Consolidation tests were completed using back-pressured consoli- 


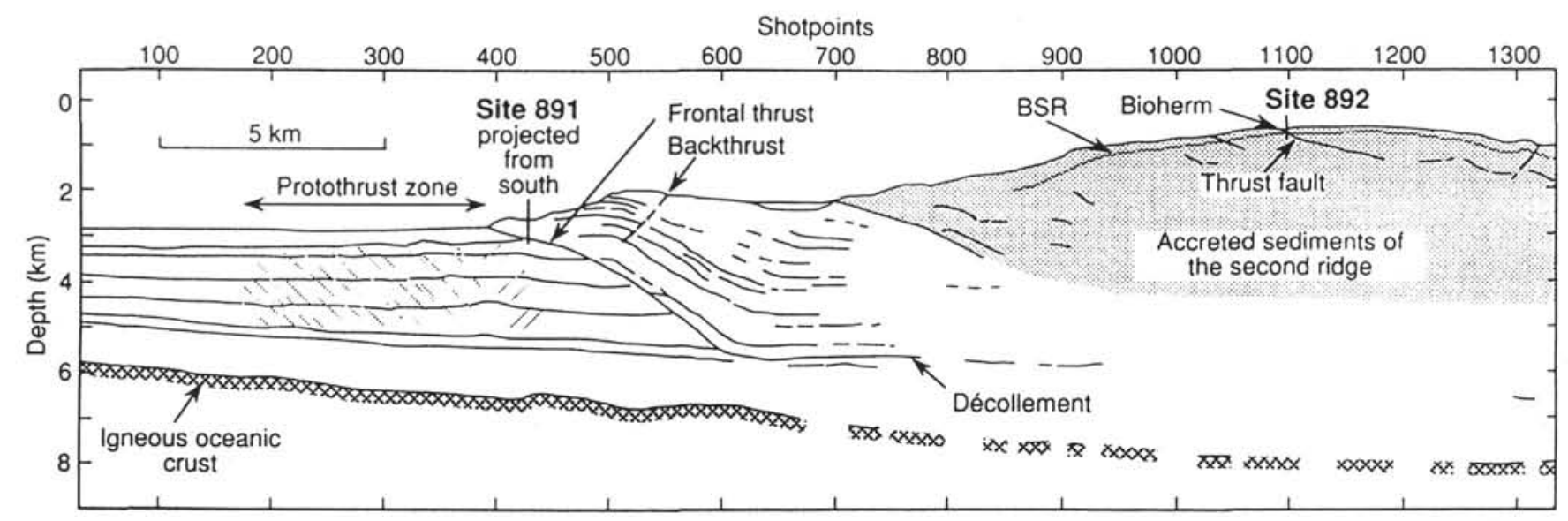

Figure 1. Line drawing of multi-channel seismic reflection line OR-9. The position of Site 892 on the second ridge is shown. The position of Site 891 is projected onto this line on the first ridge. Its actual position is approximately $3 \mathrm{~km}$ from the line (from Westbrook, 1994).

dometers, incrementally loaded at a load increment ratio of one, following procedures described by MacKillop et al. (1995). The tests are used to determine the preconsolidation stress $\left(P_{c}^{\prime}\right)$, which is interpreted as the maximum past stress; the coefficient of compression $\left(C_{c}\right)$, which is the slope of the log-linear void ratio vs. stress load curve; and the coefficient of rebound $\left(C_{r}\right)$, which is the slope of the log-linear void ratio vs. stress unload curve. $P_{c}^{\prime}$ is determined using the Casagrande construction method (Holtz and Kovacs, 1981). $P_{c}^{\prime}$ is compared with the overburden stress $\left(P_{o}^{\prime}\right)$, calculated from the sediment column buoyant unit weight. This comparison is expressed as the overconsolidation ratio (OCR) or $P_{c}^{\prime} / P_{o}^{\prime} . C_{c}$ is used to predict a normally consolidated porosity-depth curve.

Permeability values are also estimated from the consolidation tests by analyzing the incremental load data using Terzaghi's onedimensional consolidation theory, which relates the coefficient of consolidation $\left(c_{v}\right)$ to hydraulic conductivity. At each consolidation load increment, $c_{v}$ is determined and used to estimate hydraulic conductivity as follows:

$$
K=c_{v} \rho g a_{v} / 1+e_{0}
$$

where $e_{0}$ is initial void ratio, and $a_{v}$ is the slope of the incremental load-displacement curve.

\section{Proxy Methods for Determination of Stress History}

Studies in the field of petroleum geology have made important contributions to our present understanding of consolidation and stress history. Athy (1930) and Hedberg (1936) analyzed data from oil wells and developed empirical relationships between porosity and depth for clays and shales. These porosity-depth relationships take the form of logarithmic functions. Subsequent investigations have established the validity of these equations. From consolidation tests, the normally consolidated log-linear void ratio-stress curve is the direct analog for a porosity-depth function, where void ratio is equivalent to porosity through a simple phase relationship, and pressure is equated with depth through the overburden stress. Consequently, for any sediment column, its normally consolidated porosity-depth function is determined from the slope of the log-linear void ratio vs. stress curve or $C_{c}$. In this study, $C_{c}$ is used to predict the normally consolidated porosity-depth function following the methods of MacKillop et al. (1995). This predictive relationship is compared with the measured values of porosity to interpret sediment stress history.
Another proxy for estimating stress history is the undrained shear strength $\left(S_{u}\right)$ of sediment. $S_{u}$ increases with vertical effective overburden stress $\left(P_{o}^{\prime}\right)$ within a narrow range for normally consolidated finegrained sediments. This increase, expressed as the ratio $S_{u} / P_{o}^{\prime}$ varies from 0.2 to 0.25 for normally consolidated fine-grained sediment (Mesri, 1975). Ratios less than 0.2 suggest underconsolidation, as a result of lower than expected shear strengths; whereas, ratios of greater than 0.25 suggest overconsolidation and higher than expected shear strength. Shipboard-measured undrained shear strength data are compared with normally consolidated shear strength profiles, where shear strength is predicted using an $S_{u} / P_{o}^{\prime}$ of 0.2 .

\section{RESULTS \\ Consolidation}

Three consolidation tests were completed from Sites 891 and 892. Core recovery at Site 891 was poor, at less than $11 \%$ (Shipboard Scientific Party, 1994a), with total penetration to a depth of 472.3 meters below seafloor (mbsf). This low recovery precluded detailed lithostratigraphy. Recovered material is texturally and compositionally homogeneous and, therefore, defines only one lithostratigraphic unit composed of clayey silt, silt, and very fine to medium sand. However, this unit is subdivided into three subunits on the basis of mineralogic and lithologic composition (Shipboard Scientific Party, 1994a). Two samples from Site 891 were tested (Sections 146-891B-39X-2 and 146-891B-56X-2) within Subunits IB and IC, respectively (Fig. 2). Site 891 test results indicate significant underconsolidation exists based on very low $P_{c}^{\prime}$ values (Fig. 3). When presented in terms of $\mathrm{OCR}$, the values are much less than unity, which is the normally consolidated state, at $\mathrm{OCR}=0.17$ and 0.03 , respectively.

Similar to Site 891, one lithologic unit describes Site 892, a clayey silt to silty clay (Shipboard Scientific Party, 1994b). One sample was tested from within Subunit IA at Site 892 (Fig. 2). The test results (on Sample 146-892D-4X-3) show that the sediment within this thrustbound interval are normally consolidated with an OCR value of 1 (Fig. 3).

\section{Permeability}

Low-gradient permeability tests were run at selected load increments on the consolidation test samples. At each flow rate interval, fluid was pumped through the sample in both directions. Hydraulic 


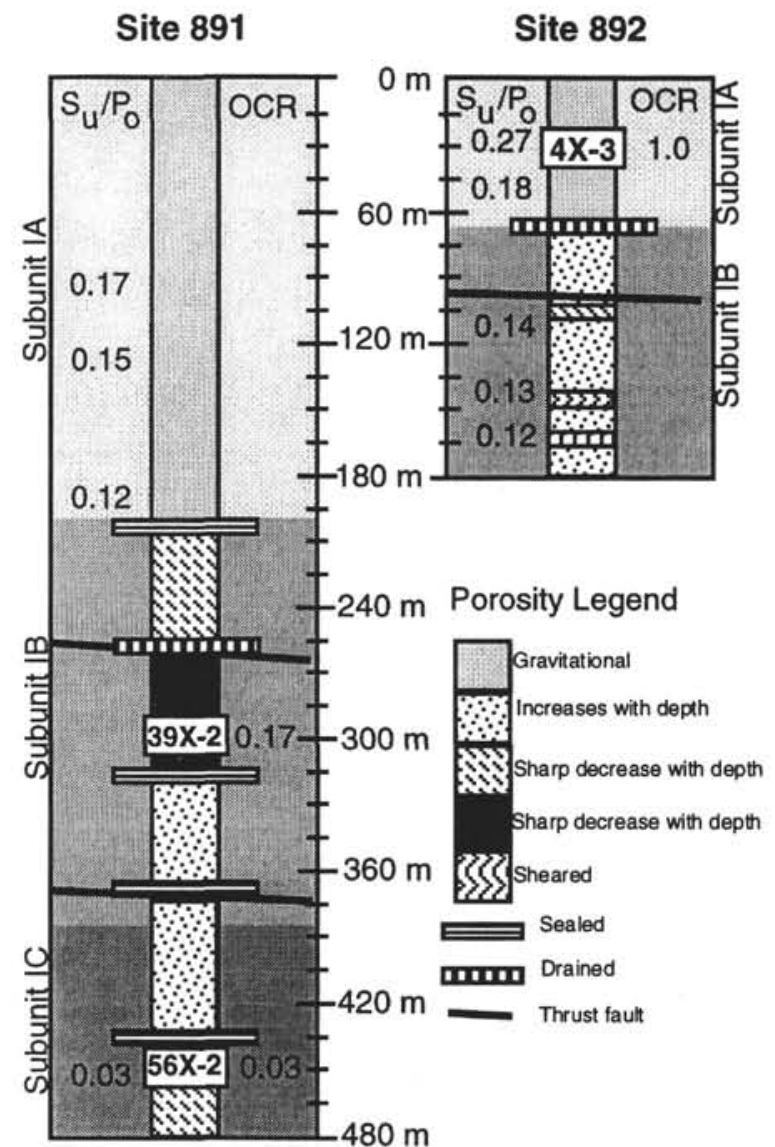

Figure 2. Simplified interpretations of the sediment properties, $S_{u} / P_{o}^{\prime}$ ratio, and OCR with interpreted positions of faults and discontinuities for Sites 891 and 892 . The locations of the samples tested for consolidation are labeled in the solid white boxes.

conductivity was determined at incremental void ratios using a minimum of four flow rates. The results show a log-linear relationship of hydraulic conductivity as a function of void ratio (Fig. 4). The tests from Site 891 result in very similar functions when logarithmic functions are fit to the measured $\mathrm{K}$ values as follows:

$$
\text { Section 146-891B-39X-2 } e=1.3+0.07 \log K \text {, }
$$

Section 146-891B-56X-2 $e=1.0+0.06 \log K$.

Site 892 results show a slightly different relationship when a logarithmic function is fit to the measured $\mathrm{K}$ values:

$$
\text { Section } 146-892-4 \mathrm{X}-3 e=2.8+0.21 \log K \text {. }
$$

The measured values are compared with estimates from the compression vs. time data for each consolidation load increment using Equation 2. For the test on Section 146-891B-56X-2, the estimated hydraulic conductivities are lower than the measured values. In the other two samples, there is generally good agreement between the calculated and measured values.

The functions represented by Equations 3 through 5 relate void ratio with hydraulic conductivity. Given the consistent lithologies at each site, these relationships can confidently be applied to the measured porosity (void ratio) values at the site to predict the matrix hy-
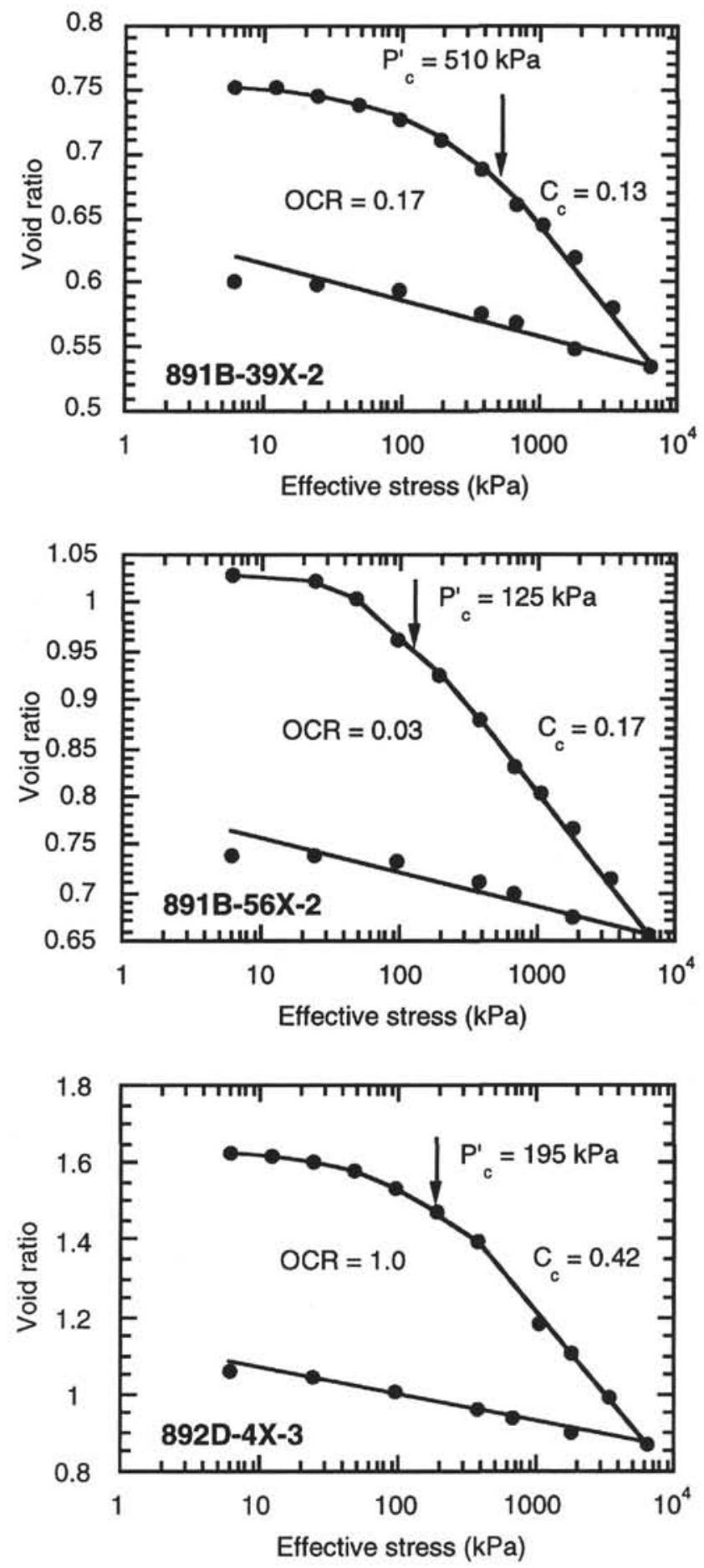

Figure 3. One-dimensional consolidation test results from Sites 891 and 892. The data are presented as $\log$ effective stress vs. void ratio. $P_{c}^{\prime}$ and OCR are labeled for each test.

draulic conductivity at depths where void ratios are higher than values equivalent to critical porosity ( $30 \%$; Katsube, 1992). The sediment critical porosity marks the change in behavior from predominantly porosity-controlled permeability to pressure-controlled permeability. The range of hydraulic conductivity values are consistent with previously reported values for typical sediments of clayey silt to silt size (e.g., Holtz and Kovacs, 1981). 


\section{Porosity-depth Function}

As a result of the low recovery rate at Site 891 , the porosity data are less comprehensive than usual Ocean Drilling Program (ODP) practice. However, the results are consistent with the other analyses reported here. At Site 891, measured porosity is compared with predicted porosity using $C_{c}$ values measured from consolidation tests (Fig. 5A). This comparison indicates normally consolidated behavior (gravitational compaction) in the upper lithologic Subunit IA where measured and predicted porosity are similar. Porosity does not vary consistently with depth in Subunits IB or IC. Within these lower units, porosity tends to be offset at regular intervals of 50 to $70 \mathrm{~m}$ (Shipboard Scientific Party, 1994a). There is an offset in porosity close to the Subunit IA/IB boundary, with four other offsets below Subunit IA, at 261, 315, 368, and 439 mbsf. These lower offsets are characterized either by lower porosity, interpreted as potential faults with drained boundaries, or by high porosity, interpreted as drained boundaries (Shipboard Scientific Party, 1994a). The position of the faults were also interpreted from the structural geology core description (Shipboard Scientific Party, 1994a).

Porosity measurements from Site 892 indicate normal to overconsolidated behavior in the upper Subunit IA (Fig. 5B). The measured values lie close to or below the normally consolidated porosity prediction curve. The base of Subunit IA marks the site of a discontinuity, below which porosity ceases to decrease consistently with depth. Subunit IB displays three offsets, at 104, 144, and 164 mbsf. The discontinuity at $104 \mathrm{mbsf}$ is interpreted as a thrust fault from seismic reflection data and the others are interpreted as possibly resulting from localized shear consolidation zones (Shipboard Scientific Party, 1994b) within faults, dewatering discrete intervals at the site.

\section{Normalized Shear Strength}

The Shipboard Scientific Party (1994a, 1994b) reported the $S_{i} / P_{o}^{\prime}$ ratios for Sites 891 and 892 . This ratio is less than our estimated minimum normally consolidated value $(0.2)$ for all intervals of Hole 891B, suggesting underconsolidated sediment (Fig. 2). At Site 892, $S_{t} / P_{o}^{\prime}$ values are in the normal to slightly overconsolidated range within Subunit IA and in the underconsolidated range in Subunit IB (Fig. 2).

\section{DISCUSSION}

Shipboard index property results suggest several porosity offsets. Three offsets are coincident with faults identified from the seismic reflection data. Others form two categories: drained boundaries, characterized by lower porosity at the boundary, and sealed boundaries, characterized by higher porosity at the boundary (Fig. 1). We suggest that drained boundaries are likely zones of high permeability, caused either by fracturing or by coarser sediment, capable of transmitting fluid relatively easily, whereas sealed boundaries are of low permeability, caused either by very tight, unfractured clays or by a zone of higher excess pore fluid pressure, and do not pass fluids easily. The position of these boundaries allows for a comprehensive interpretation of OCR values, shear strength, porosity trends, and permeability.

The overconsolidation ratios derived for the three samples are useful indicators of stress history. The sample from Hole 892D exhibits an OCR of 1.0, suggesting normal consolidation. This interpretation is consistent with the average of $S_{u} / P_{o}^{\prime}$ values $(0.27)$ within the upper subunit at this site. The sediments of the second ridge consist of an accreted, thrust-bounded package of Pliocene basin fill. However, Section 146-892D-4X-3, at a depth of only $30.45 \mathrm{mbsf}$, does not represent these older accreted materials and instead consists of material deposited subsequent to the uplift of the second ridge. As such,
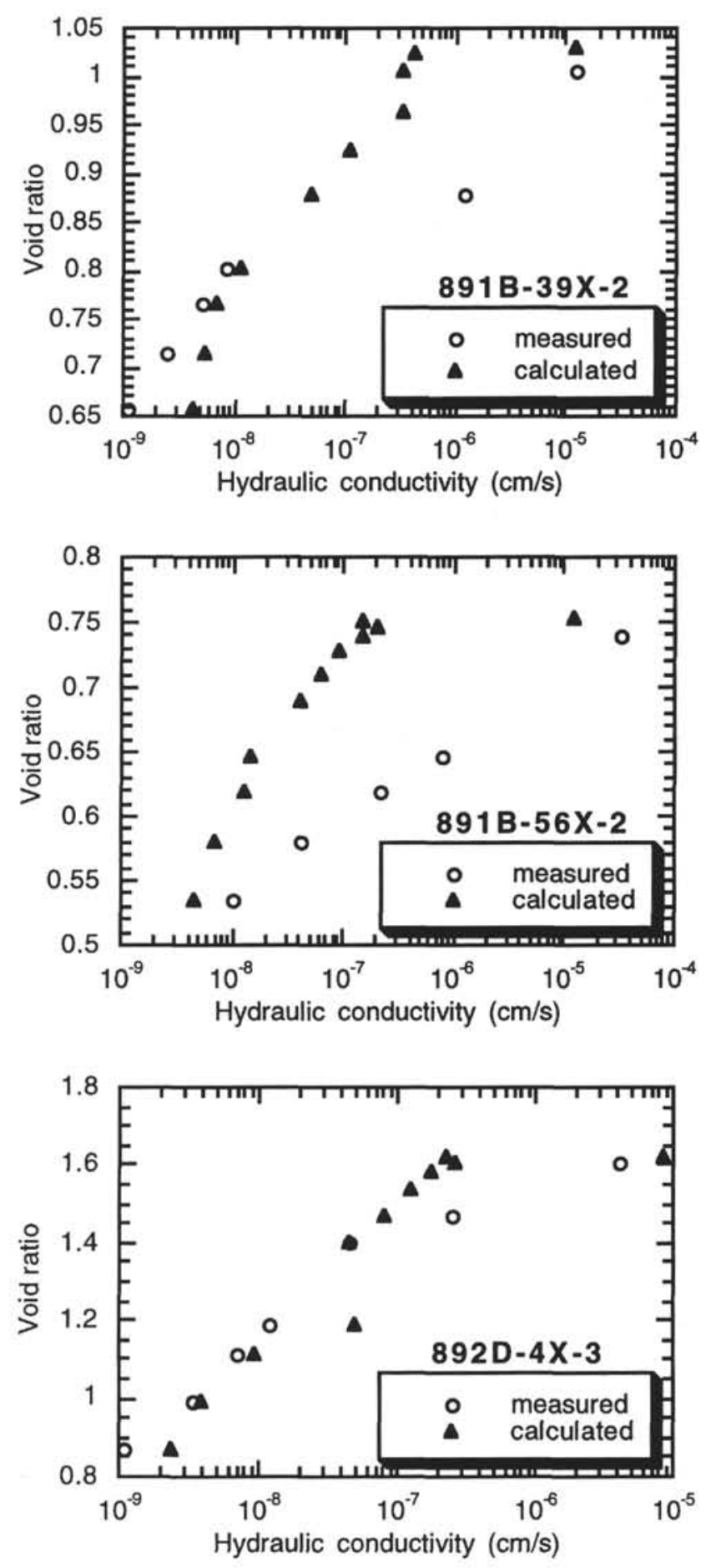

Figure 4. Results from low-gradient permeability tests (open circles) and values estimated from the coefficient of consolidation (solid triangles) plotted as a function of void ratio. Each circle is determined from a minimum of eight flow-rate tests. Note the log-linear relationship of the measured values of permeability as a function of void ratio.

this sediment package may represent sediment properties before accretion. This interpretation allows the use of results from the sample as a reference point for interpreting accretion related changes.

Results from consolidation tests from Site 891, yield an OCR of 0.17 at $297 \mathrm{mbsf}$ and an OCR of 0.03 at $447 \mathrm{mbsf}$. These OCR values suggest a high state of underconsolidation. Thrust faults, identified 

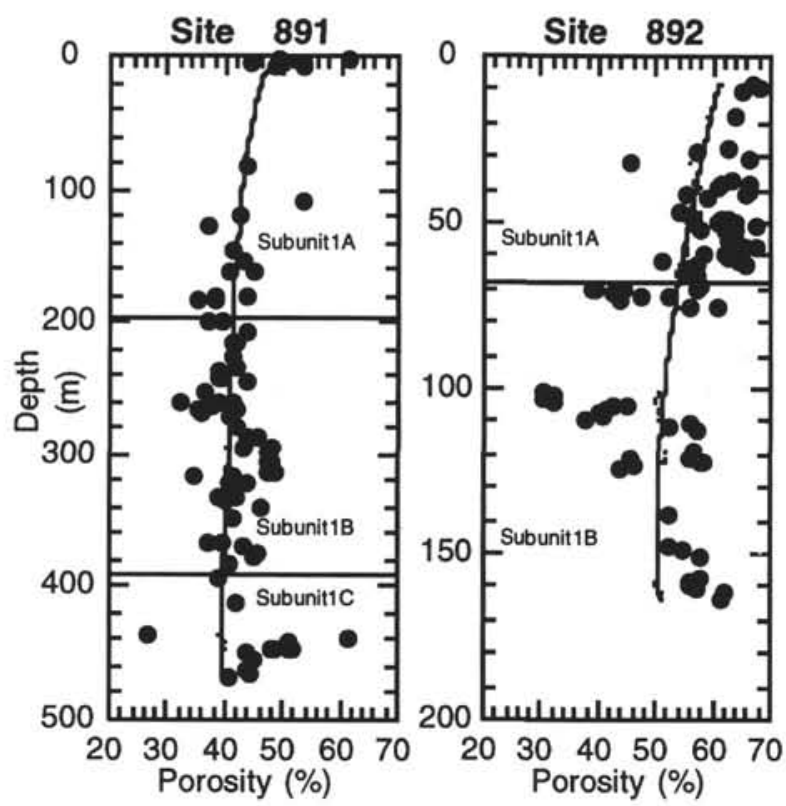

Figure 5. Porosity measurements (circles) compared with the normally consolidated porosity curve predicted using the coefficient of compression for (A) Site 891 and (B) Site 892.

from seismic reflection data, are positioned approximately 30 and 70 $\mathrm{m}$ above each sample, indicating that the tested intervals comprise underthrust sediments. The process of underthrusting results in increased thicknesses of overburden and consequently increased load stresses. These increased load stresses develop excess pore pressures if the loading occurs faster than the sediment permeability can accommodate pressure dissipation. The $S_{u} / P_{o}^{\prime}$ results at Site 891 are consistent with this interpretation (Fig. 2). Similarly, the measured porosity values below $270 \mathrm{mbsf}$ are higher than the predicted normal consolidated porosity (Fig. 5).

In situ hydraulic conductivity is estimated using the minimum void ratio at stresses below the onset of virgin compression. Using this void ratio, we find the corresponding hydraulic conductivity from Equations 3-5. Void ratios of 1.53,0.68, and 0.85 , are derived for Sections 146-892D-4X-3, 146-891B-39X-2, 146-891B-56X-2, respectively. These values correspond to in situ estimates of hydraulic conductivities of $8.9 \times 10^{-7}, 1.9 \times 10^{-9}, 3.1 \times 10^{-3} \mathrm{~cm} / \mathrm{s}$, respectively. The in situ value for the shallow sediment at Site 892 is low but consistent with typical marine fine-grained sediments (e.g., Clukey and Silva, 1982). At the samples' positions at Site 891, the estimated in situ hydraulic conductivity values vary widely $\left(10^{-9}\right.$ to $\left.10^{-3} \mathrm{~cm} / \mathrm{s}\right)$. The lower value is consistent with the other data presented here, which suggests high excess pore pressure most likely attributed to this very low permeability when compared with the high rates of loading at this site from thrusting. At first glance, the very high value seems contradictory. However, it can be explained by the faults throughout the site that form drained vs. sealed boundaries.

Although the permeability of the deepest sample is relatively high at Site 891 , the porosity function does not suggest a drained condition. The interval from which this sample was recovered is probably bounded by a sealed boundary (Fig. 2). This boundary could be a high fluid pressure seal within the fault, as has been proposed for other accreted sites by Karig et al. (1990). Thus, drainage of this high-permeability sediment could be restricted by this proposed pressure seal.

Pore-water pressures greater than hydrostatic are called excess pore pressures. Estimates of excess pore pressures are made by subtracting the preconsolidation stress $\left(P_{c}^{\prime}\right)$ from the vertical effective overburden stress $\left(P_{o}^{\prime}\right) . P_{c}^{\prime}$ approximates the maximum effective stress applied over the sediment interval. Consequently, the stress difference between $P_{c}^{\prime}$ and $P_{o}^{\prime}$ must be supported by the pore fluid, in excess of hydrostatic. At Hole 892D, within Subunit IA, no excess pore pressure is present. The underconsolidated sediments of Hole 891B exhibit quite different results. The shallower test results in an excess pore pressure of $2.5 \mathrm{MPa}$, and the deeper sample results in a large excess pore pressure of $4.5 \mathrm{MPa}$. The increase in excess pore pressure, estimated from this study, shows a relationship to the sediment loading at Site 891, as Section 146-891B-39X-2 may have been underthrust once, whereas Section 146-891B-56X-2 may have been underthrust twice. This relationship supports models of excess pore pressure generation that place more emphasis on tectonic loading, rather than tectonic compression, as the largest factor influencing overpressure generation.

\section{SUMMARY}

Within Subunit IA of Site 892, the sediment is normally consolidated as shown by an OCR of 1.0 from the consolidation test results. This interpretation is supported by the $S_{u} / P_{o}^{\prime}$ results and the porositydepth function, which suggest normal to slightly overconsolidated states.

The results from porosity data and $S_{u} / P_{o}^{\prime}$ suggest that the upper $100 \mathrm{~m}$ of Subunit IA of Site 891 may also be normally consolidated. Below this depth at Site 891, however, the sediment is underconsolidated as shown by the very low OCR values in Subunits IB and IC. This underconsolidation is consistent with an interpretation of high excess fluid pressure, resulting from rapid vertical loading of the sediment column from thrusting.

Excess pore pressures of the high magnitudes found at Site 891 can reduce vertical effective stresses to nearly zero, resulting in a loss of frictional cohesion between sediment grains. Hubbert and Rubey (1959) suggested this loss of cohesion as a mechanism for large thrust-block movement, occurring as pore pressures approach lithostatic values. To evaluate pore pressure conditions, Hubbert and Rubey define a pore-pressure parameter, calculated as the ratio of pore pressure over the lithostatic stress. When the pore-pressure parameter, $\lambda$, reaches a value of 1 , sediment is at failure conditions. Coulomb wedge modeling (Davis et al., 1983) predict values of $\lambda$ at the décollement of 0.90 for Oregon Margin, based on its geometry. Results from this study at Site 891 (excess pore pressures of 2.5 and $4.5 \mathrm{MPa}$ ) result in values of $\lambda$ of 0.83 to 0.97 . This suggests that the deeper interval at Site 891 is very close to failure.

\section{REFERENCES}

Athy, L.F., 1930. Density, porosity, and compaction of sedimentary rocks. AAPG Bull., 14:1-24.

Clukey, E.C., and Silva, A.J., 1982. Permeability of deep-sea clays: Northwestern Atlantic. Mar. Geotechnology, 5:1-25.

Davis, D., Suppe, J., and Dahlen, F.A., 1983. Mechanics of fold-and-thrust belts and accretionary wedges. J. Geophys. Res., 88:1153-1172.

Hedberg, H.D., 1936. Gravitational compaction of clays and shales. Am. J. Sci., 31:241-287.

Holtz, R.D., and Kovacs, W.D., 1981. An Introduction to Geotechnical Engineering: Englewood Cliffs, NJ (Prentice-Hall).

Hubbert, M.K., and Rubey, W.W., 1959. Role of fluid pressure in mechanics of overthrust faulting, I. Mechanics of fluid-filled porous solids and its application to overthrust faulting. Geol. Soc. Am. Bull., 70:115-166.

Karig, D.E., Moran, K., and Leg 131 Scientific Party, 1990. A dynamically sealed décollement: Nankai prism. Int. Conf. on Fluids in Subduction Zones, Paris. (Abstract)

Katsube, T.J., 1992. Statistical analysis of pore-size distribution data of tight shales from the Scotian Shelf. Pap.-Geol. Surv. Can., 92-1E:365-372.

Langseth, M.G., and Moore, J.C., 1990. Introduction to special section on the role of fluids in sediment accretion, deformation, diagenesis, and metamorphism in subduction zones. J. Geophys. Res.,95:8737-8741. 
MacKillop, A.K., Moran, K., Jarrett, K., Farrell, J., and Murray, D., 1995. Consolidation properties of equatorial Pacific Ocean sediments and their relationship to stress history and offsets in the Leg 138 composite depth sections. In Pisias, N.G., Mayer, L.A., Janacek, T.R., Palmer-Julson, A., and van Andel, T.H. (Eds.), Proc. ODP, Sci. Results, 138: College Station, TX (Ocean Drilling Program), 357-369.

Mesri, G., 1975. Discussion of new design procedures for stability of soft clays. J. Geotech. Div., Am. Soc. Civ. Eng., 101-GT4:409-412.

Shipboard Scientific Party, 1994a. Site 891. In Westbrook, G.K., Carson, B., Musgrave, R.J., et al., Proc. ODP, Init. Repts., 146 (Pt. 1): College Station, TX (Ocean Drilling Program), 241-300.

1994b. Site 892. In Westbrook, G.K., Carson, B., Musgrave, R.J., et al., Proc. ODP, Init. Repts., 146 (Pt. 1): College Station, TX (Ocean Drilling Program), 301-378.
Terzaghi, K., 1943. Theoretical Soil Mechanics: New York (Wiley).

Westbrook, G.K., 1994. Growth of accretionary wedges off Vancouver Island and Oregon. In Westbrook, G.K., Carson, B., Musgrave, R.J., et al., Proc. ODP, Init. Repts., 146 (Pt. 1): College Station, TX (Ocean Drilling Program), 381-388.

Date of initial receipt: 8 September 1994

Date of acceptance: 31 May 1995

Ms 146SR-225 